\title{
AROUND THE WORLD
}

Village Day is also planned which will include seven parallel, fullday programmes. The congress will take place at ExCeL, while social events will take place at venues including Madame Tussauds, the Natural History Museum and Old Billingsgate Market.

\section{Turning Japanese}

Following London 2015, 2020 will see the congress held in Asia for the first time - in 2012 the WFO executive committee announced that the Japanese Orthodontic Society (JOS) had been selected to co-host the 9th IOC in 2020. The event will be held at Japan's largest convention complex, the Pacifico Yokohama Convention Complex, in the port city of Yokohama from 4-7 October 2020. ${ }^{10}$

For the full programme and further information, visit the IOC website at: http://wfo2015london.org.

1. World Federation of Orthodontists. Past IOC meetings. Online information available at http://www.wfo.org/meetings/ past-ioc-meetings/ (accessed August 2015).

2. Rose JS, Campbell AC, Eirew HL, Gould MSE, Leighton BC, Rose RJ, Savage M. A History of the British Orthodontic Societies (1907-1994). London: British Orthodontic Society, 2002.

3. Dewel BF. The International Orthodontic Congress: An educational and cultural event. Am J Orthod 1973; 63: 644-647.

4. Sandler J. International Orthodontic Congress, London 2015 - how we got there! J Orthod 2010; 37: 231-233.

5. European Orthodontic Society. Presidents of the European Orthodontic Society. Online information available at (accessed August 2015)

6. World Federation of Orthodontists. History. Online information available at http:// www.wfo.org/about-wfo/history/ (accessed August 2015)

7. World Federation of Orthodontists. The 7th International Orthodontic Congress. Online information available at http://www.wfo. org/meetings/past-ioc-meetings/the-7thinternational-orthodontic-congress/ (accessed August 2015).

8. Sandler J. The Eighth International Orthodontic Congress. J Orthod 2015 42: 1-2.

9. World Federation of Orthodontists. The 8th International Orthodontic Congress. Online information available at http:// wfo2015london.org/ (accessed August 2015)

10. World Federation of Orthodontists. The 9th International Orthodontic Congress. Online

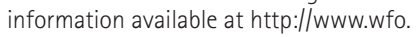
org/meetings/2020-the-9th-international-orthodontic-congress/ (accessed August2015).

\section{America}

Owing to their dental health issues a substantial number of American children miss school, a Delta Dental Plans Association survey has found. More than 30\% of the parents interviewed reported that their children had missed school for oral health-related issues. The results indicated that children's absence from school varied by region and parents' age.

In the survey, investigators conducted email interviews with 1,325 parents of children up to the age of 12 . They found that more schoolchildren in the Northeast states missed school owing to dental issues than those in other regions, since 36\% of parents reported that their children had been absent from school. Schoolchildren in the South came second with 33\%, followed by the Midwest and the West with 28\% each. When asked about the number of school days their children had missed, 18\% of parents stated that their children had missed at least half a day of school. Four percent reported one missed day, another 4\% noted two days of absence and 6\% stated that their children had missed three or more days because of dental problems.

\section{Thailand}

With the newly opened Sirindhorn Dental Museum, the Faculty of Dentistry at Mahidol University in Bangkok has introduced the first dental museum of its kind in Asia. By highlighting the history of dentistry and oral hygiene across Asia through fun and interactive exhibits, the museum hopes to raise awareness in the country about the importance of proper oral care.

The $620 \mathrm{~m}^{2}$ museum, which is sponsored by the royal family, features five main exhibits, each aimed at improving understanding of the importance of good dental health. "We want to ensure that Thais will have a healthy smile in our "Land of Smiles" for as long as possible,' Dr Phira Sithiamnuai, assistant professor and Deputy Dean for Collaboration and Networking at the Faculty, told the Bangkok Post last week. 'Our goal for the museum is to encourage Thai children to understand the importance of oral health in an entertaining way. We hope that learning with fun will inspire people to make healthy choices about their oral health.'

\section{Europe}

The Platform for Better Oral Health in Europe is hosting its second European Oral Health Summit in the European Parliament in Brussels on 13 October. The event aims to discuss new ways to improve oral health in Europe by presenting examples of best practices in oral health promotion and preventative measures from across the EU.

The platform was initiated in 2010 as a response to the Call to Action for Better Oral Health in Europe that was handed over to former European Health Commissioner John Dalli by several members of the European Parliament. The mission of the platform is to promote oral health and the cost-effective prevention of oral diseases in Europe. Moreover, it aims to foster a common European approach towards education, prevention and access to better oral health in the EU.

\section{Australia}

A study, recently reported in the $B D J$ and conducted at the University of Western Australia, has shown that prophylactic removal of third molars costs the Australian health system more than $\mathrm{A} \$ 500$ million a year. Researchers also stated that specific guidelines on removal of asymptomatic third molars could reduce costs dramatically.

To develop a national level cost model and guidelines, the researchers analysed costs associated with hospitalisations for impacted teeth in 2008 and 2009 in Australia. They determined that there were an estimated 97,949 such hospitalisations of Australians aged 15-34 in the period examined. The estimated average annual direct cost was A\$350 million, the indirect cost was $\mathrm{A} \$ 181$ million and the total cost was $\mathrm{A} \$ 531$ million. The investigators suggested that implementing new guidelines for treatment of impacted teeth would lead to an annual figure of 83,850 individuals not being hospitalised. 